\title{
LIM and SH3 Domain Protein 1
}

National Cancer Institute

\section{Source}

National Cancer Institute. LIM and SH3 Domain Protein 1. NCI Thesaurus. Code C97606.

LIM and SH3 domain protein 1 (261 aa, $30 \mathrm{kDa}$ ) is encoded by the human LASP1 gene.

This protein is involved in the regulation of actin-associated transport. 